\title{
Myiasis in three species of Bokermannohyla (Hylidae, Anura)
}

\author{
GIULIANA FRANKLIN LEMOS', LEO RAMOS MALAGOLI² \& \\ RICARDO LOURENÇO-DE-MORAES ${ }^{3 *}$
}

\begin{abstract}
1Programa de Pós-graduação em Ecologia de Ambientes Aquáticos Continentais, Universidade Estadual de Maringá, Av. Colombo, 5790, Jardim Universitário 87020-900, Maringá, Paraná, Brazil

${ }^{2}$ Laboratório de Herpetologia, Departamento de Zoologia e Centro de Aquicultura (CAUNESP), Instituto de Biociências, Universidade Estadual Paulista (UNESP), Av. 24A, 1515, Bela Vista 13506-900, Rio Claro, São Paulo, Brazil

${ }^{3}$ Programa de Pós-graduação em Ecologia e Monitoramento Ambiental (PPGEMA), Universidade Federal da Paraíba (UFPB), Campus IV, Litoral Norte, Av. Santa Elizabete s/n, Centro, 58297-000, Rio Tinto, PB, Brazil

${ }^{*}$ Corresponding author e-mail: ricardo_Imoraes@hotmail.com
\end{abstract}

$\mathrm{M}$ yiasis is an ectoparasitic infection of animal tissue by the larvae of flies in the families Sarcophagidae, Calliphoridae, and Chloropidae (Marcondes, 2009). In amphibians, the deposition of larvae occurs through natural orifices, healthy skin and exposed wounds, leading to the death of the host (Reichenbach-Klinke \& Elkan, 1965; Bolek \& Coggins, 2002; Bolek \& Janovy, 2004). In the present study, cases of myiasis are presented in three species of tree frog, Bokermannohyla hylax (Heyer, 1985), Bokermannohyla caramaschii (Napoli, 2005) and Bokermannohyla luctuosa (Pombal \& Haddad, 1993), from different areas inserted in the morphoclimatic domain of the Atlantic Forest of eastern Brazil.

The first $B$. hylax specimen observed and filmed (not collected) was on 8 November 2014, 11.30h at the Parque Estadual da Serra do Mar, Núcleo Santa Virgínia $\left(23^{\circ}\right.$ $20^{\prime} 37.10^{\prime \prime}$ S, $45^{\circ} 8^{\prime} 19.29^{\prime \prime}$ W), municipality of São Luís do Paraitinga, State São Paulo. Bokermannohyla caramaschii was subsequently collected in February 2015, 20.30h at the Reserva Biológica Augusto Ruschi ( $19^{\circ} 54^{\prime} \mathrm{S}, 40^{\circ} 33^{\prime} \mathrm{W}$ ) in the municipality of Santa Teresa, State Espírito Santo and $B$. luctuosa was collected in December $2015,18.30 \mathrm{~h}$ at the Parque Estadual de Campinhos ( $25^{\circ} 02^{\prime} \mathrm{S}, 49^{\circ} 05^{\prime} \mathrm{W}$ ) in the municipality of Tunas do Sul, State Paraná. The specimens were collected manually and stored in plastic bags. Both the hosts and the fly larvae were fixed in $70 \%$ ethyl alcohol.

The mechanism of $B$. hylax larval deposition adopted by the fly was observed and filmed (YouTube, 2019). First, the fly rests on the host's head and moves laterally toward the loreal region of the frog. It then deposits the larvae on the back of the jaw. During the process the frog attempts to get rid of the larva, trying to remove it with repeated movements of the hands and sometimes endeavours to escape by jumping. The fly may repeat this procedure on several occasions, depositing one larva at a time. The larva migrates to the tympanum and probably penetrates and moves into the internal gular region of the host (Fig. 1 A-D).

In all cases the anurans were found on the ground and showed slow, unbalanced movements. A few hours after capture, the gular region of the specimens was ruptured by the exit of the fly larvae, leading to death of the species (observed in B. caramaschi and B. luctuosa). With the aid of stereomicroscopy (Leica $E Z 4^{\circledR}{ }^{\circledR}$ ), it was possible to observe that the anurans had a small perforation (hole) in the tympanic membrane (Fig. 1 E-H).
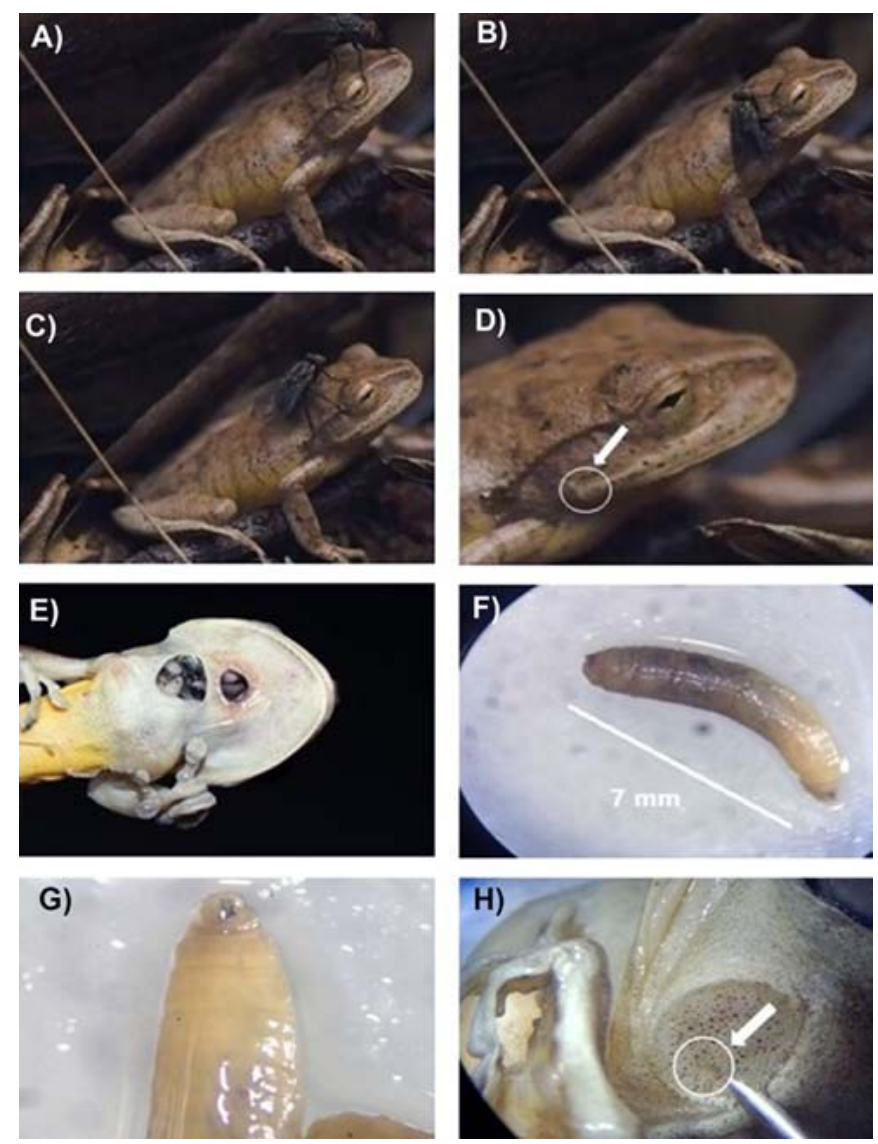

Figure 1. Fly landing and depositing a larva on the host B. hylax; A) Fly landing on host's head; B) Fly landing and depositing a larva near the host tympanum; C) Fly returning to host's head ; D) Arrow pointing to the larva (body size $~ 0.5 \mathrm{~mm}$ ); E) Developed larvae breaking the skin of the host while it is still alive (host B. caramaschii); F) Body size of larva $(7.5 \mathrm{~mm})$ after removal from host (B. luctuosa); G) Details of the mouth of the larva; and $\mathbf{H}$ ) Tympanum of the host pierced by the larva (host B. luctuosa) 
Müller et al. (2015) reported the presence of perforations caused by sarcophagid larvae along the body of individuals of the genus Leptodactylus. Oliveira et al. (2012), observed lesions above the cloaca, where the parasites were housed in frogs of the genus Boana. In both the above cases, the anurans in question exhibited nocturnal activity, as was the case with the species reported in this study. Therefore, the active period of the frogs does not coincide with that of the flies, which makes them more vulnerable.

\section{ACKNOWLEDGEMENTS}

We thank to Rafael Guadeluppe for kindly shared the filming of B. hylax, and Rick Hodges, John Cooper, and Margaret Cooper for their careful reading of the manuscript and suggestions. RLM (151473/2018-8) and LRM (141259/20140) thank the Conselho Nacional de Desenvolvimento Científico e Tecnológico (CNPq) for scholarships. This study was financed in part by the Coordenação de Aperfeiçoamento de Pessoal de Nível Superior - Brasil (CAPES) - Finance Code 001. Collection permits were issued by COTEC/IF (260108003.523/2014) and Instituto Chico Mendes de Conservação da Biodiversidade (ICMBio: 45665-1).

\section{REFERENCES}

Bolek, M.G. \& Coggins, J.R. (2002). Observations on myiasis by the calliphorid, Bufolucilia silvarum, in the eastern American toad (Bufo americanus americanus) from southeastern Wisconsin. Journal of Wildlife Diseases 38: 598-603.
Bolek, M.G. \& Janovy, J. (2004). Observations on myiasis by the calliphorids, Bufolucilia silvarum and Bufolucilia elongata, in the wood frogs, Rana sylvatica from Southeastern Wisconsin. Journal of Parasitology 90: 1169-1171.

Haddad, C.F.B., Toledo, L.F., Prado, C.P.A., Loebmann, D., Gasparini, J.L. \& Sazima, I. (2013). Guia dos Anfíbios da Mata Atlântica: Diversidade e Biologia. São Paulo: Anolis Books. 544 pp.

Hall, M.J.R. \& Walls, R. (1995). Myiasis of humans and domestic animals. Advances in Parasitology 35: 257-334.

Marcondes, C. B. (ed.). (2009). Doenças transmitidas e causadas por artropodes. Editora Atheneu, Sao Paulo, Brazil. 557 pp.

Müller, G.A., Lehn, C.R., Bemvenuti, A. \& Marcondes, C.B. (2015). First report of myiasis (Diptera: Sarcophagidae) in anuran of Leptodactylidae (Amphibia). Revista Colombiana de Ciencia Animal 7: 217-220.

Oliveira, R.M., Mira-Mendes, C.V., Ruas, D.S., Solé, M., Pinho, L.C. \& Rebouças, R. (2012). Myiasis on Hypsiboas atlanticus (Caramaschi \& Velosa, 1996) (Anura: Hylidae) from Southern Bahia, Brazil. Herpetology Notes 5: 493494.

Reichenbach-Klinke, H.H. \& Elkan, E. (1965) Principal Diseases of Lower Vertebrates. Academic Press, London. 612 pp.

YouTube (2019) Lemos et al Myiasis in three species of the genus. https://www.youtube.com/watch?v=-IZhkYx2ljE \&feature=youtu.be. Uploaded December 2019.

Zumpt, F. (1965). Myiasis in Man and Animals in the Old World. A textbook for physicians, veterinarians and zoologists. London, Butterworth. 267 pp.

Accepted: 31 October 2019 